\title{
The effect of the amount and type of dietary fat on milk fat secretion in the cow
}

\author{
BY J. E. STORRY, J. A. F. ROOK* AND A. J. HALL \\ National Institute for Research in Dairying, Shinfield, Reading
}

(Received 7 October 1966-Accepted 4 fanuary 1967 )

\begin{abstract}
I. Two experiments are described in which the effects of dietary fat on the synthesis of milk fat in the dairy cow have been investigated. In the first experiment a change-over design was used with two cows to study the effect of removing a mixed-oil supplement to a basal diet low in fat on the concentration and composition of plasma lipids and on the yield and composition of milk fat.

2. Reducing the dietary fat intake from about 430 to $170 \mathrm{~g} /$ day caused falls in the concentrations in plasma of phospholipid and of free and esterified cholesterol and, in one cow, also of triglyceride. The changes in composition and concentration of the fatty acids in the plasma triglyceride fraction also reflected changes in dietary intake of fatty acids. No effect of dietary fat intake on the total synthesis of milk fat was observed, but the composition of the milk fat reflected that of the dietary fat, and the yields of lauric, myristic, stearic and oleic acids were decreased in association with a decreased dietary intake of these acids.

3. In the second experiment the effect of supplementing a basal diet low in fat with either coconut, red palm or groundnut oil on the composition and yield of milk fat was studied in four cows using a $4 \times 4$ Latin square design balanced with respect to residual effects.

4. With each oil, increasing the dietary fat intake from about 100 to $400 \mathrm{~g} /$ day significantly increased the total yield of milk fat. Also, coconut and red palm oils significantly increased the fat content of milk, and groundnut oil the yield of milk.

5. With the exception of linoleic and palmitic acids, the increased dietary intake of the major fatty acids characteristic of the various oil supplements led to increased yields of these acids in the milk.
\end{abstract}

Tritium-labelled stearic acid administered orally, as either free acid or triglyceride, to lactating goats and cows appears in the blood plasma mainly in the triglycerides of the $\beta$-lipoproteins and is then selectively removed from the blood by the udder and secreted in milk fat (Glascock, Duncombe \& Reinius, 1956; Glascock, McWeeny \& Smith, 1957; Glascock, Welch, Bishop, Davies, Wright \& Noble, 1966). The intravenous infusion of tritium-labelled chylomicra into conscious lactating goats, and the perfusion of isolated goat mammary glands with similarly labelled chylomicra, have confirmed that the udder of the lactating ruminant rapidly removes, for the formation of milk fat, a large proportion of the chylomicra entering the circulation (Lascelles, Hardwick, Linzell \& Mepham, I964). Furthermore, there is a considerable difference in the arteriovenous concentrations of plasma triglycerides actoss the udder of lactating, but not of dry cows (Hartmann \& Lascelles, 1964), and in the goat similar more detailed studies have shown that it is mainly stearic and palmitic acids in the triglycerides of the chylomicra and lipoproteins of density $I^{\cdot 005}-\mathrm{I} \cdot 019$ which are taken up by the mammary gland (Barry, Bartley, Linzell \& Robinson, 1963). The short-term intravenous administration of emulsified cottonseed oil, which is rich in linoleic acid, is associated with the appearance of linoleic acid in the milk fat in high concentration (Tove \& Mochrie, I963), and long-term infusions of this oil cause

\footnotetext{
* Present address: Department of Agriculture, University of Leeds.
} 
massive increases in the secretion in milk fat of linoleic acid, with partial compensatory decreases in the secretion of oleic and stearic acids (Storry \& Rook, 1964).

Although there is, therefore, conclusive evidence that the mammary gland takes up long-chain fatty acids from blood triglycerides for the formation of milk fat, the quantitative significance of this process under normal physiological conditions is not established, and in the literature there are many conflicting results as to the effect of the amount and type of fat in the diet of the cow and goat on the yield and composition of milk fat. The feeding of highly unsaturated fish oils, for example cod-liver oil, has been found consistently to reduce the fat content of the milk, sometimes in association with a fall in milk yield, and the resulting milk fat is more unsaturated in composition (Brown \& Sutton, 1931 ; Petersen, I932; McCay \& Maynard, I935; Garner \& Sanders, 1938; Moore, Hoffman \& Berry, I945; McDowall, Reid \& Patchell, I957; Shaw \& Ensor, 1959). The reduction in milk fat produced by the feeding of cod-liver oil may result indirectly from altered proportions of the steam-volatile fatty acids in the rumen or more directly from the unsaturated acids in the oil affecting intermediary metabolism in the body or mammary gland (Sutton, I965). On the other hand, the feeding of tallow and of oils of plant origin has had variable effects on the content and yield of fat in milk, and the fatty acid composition of the milk is altered to some extent towards that of the added fat, particularly when the fat contains mainly fatty acids which are not subject to hydrogenation and metabolism by the rumen flora (for references see Rook, I961; Garton, I963; Van Soest, I963). Part of the variation in response to dietary fat may be due to differing experimental conditions, as for example the quantity, frequency and length of period of feeding with the fat. Also the quantity and quality of fat in the basal diet may be an important factor and, apart from a few early reports in which solvent-extracted diets containing virtually no fat were compared with unextracted diets (Bender \& Maynard, 1932; Maynard \& McCay, 1929-30), most experiments have apparently been carried out with basal diets already providing a 'normal' quantity of fat, and it is likely that under these conditions animals respond less markedly to further increases in dietary fat.

Studies on the effect of dietary fat on the concentration of plasma lipids have been limited mainly to observations on total lipid (Maynard, McCay \& Madsen, I936; Stull, Harland \& Davis, r957; Bohman, Wade \& Torell, 1959) or its major fractions, namely the phospholipid and free and esterified cholesterol, the concentrations of which in plasma are positively correlated with the level of dietary fat (Maynard \& McCay, r929-30, 1932; Bender \& Maynard, I932; Williams \& Maynard, 1934; Bohman, Wade \& Torell, I962; Bohman \& Lesperance, I962). In the adult sheep, however, the concentration of triglyceride in plasma appears to be relatively insensitive to the amount of fat in the diet (Leat $\&$ Gillman, r 964) and the effect of dietary fat on the fatty acid composition of the triglyceride fraction of plasma lipid has not been investigated.

The experiments described here were therefore done to obtain more information on the effect of dietary fat on the concentrations in the blood plasma of the main lipid fractions, on the fatty acid composition of the triglycerides, and on the yield and composition of milk fat. 


\section{EXPERI MENTAL}

Animals and their management. Two experiments were done. One Shorthorn cow $(\mathrm{M} 98)$ and one Ayrshire cow $\left(\mathrm{S}_{3}\right)$ were used in the first experiment and four Friesian cows in the second. All animals were in the 2nd month of lactation at the beginning of experiments.

Expt I was designed to study the effect of removal of a fat supplement from the diet on the blood lipids and on milk fat secretion. The cows were offered a basal diet of $5 \mathrm{~kg}$ meadow hay, $4-5 \mathrm{~kg}$ sugar-beet pulp and 8-9 $\mathrm{kg}$ of a concentrate mixture containing barley $(21 \cdot 2 \%)$, rice $(15.4 \%)$, tapioca $(15.4 \%)$, decorticated groundnut cake $(3 \mathrm{r} \cdot 7 \%)$, blood meal ( $10.6 \%)$, minerals $(\mathrm{I} \cdot 9 \%)$, and fat $(4.0 \%)$. The fat supplement was a mixture of equal parts of coconut oil, groundnut oil and linseed oil. The fat (ether extract) content of the hay was $1.4 \%$, of the sugar-beet pulp $0.3 \%$ and of the concentrate mixture before addition of the fat $\mathrm{r} .0 \%$. The total daily fat intake on the unsupplemented ration was 162 and $175 \mathrm{~g}$ and on the fat-supplemented ration $4 \mathrm{IO}$ and $454 \mathrm{~g}$ for cows $\mathrm{S}_{3}$ and $\mathrm{M}_{9} 8$ respectively. Experimental periods were of $2 \mathrm{I}$ days, and $S_{3}$ and $M_{9} 8$ were kept on experiment for a total of 63 and ${ }_{105}$ days respectively. At the end of each $2 \mathrm{I}$-day period the quantity of food was reduced by $0.2 \mathrm{~kg}$ hay, $0.2 \mathrm{~kg}$ sugar-beet pulp and $0.4 \mathrm{~kg}$ concentrate mixture. During the second $2 \mathrm{I}$-day period the fat was omitted from the concentrate mixture and the weight of mixture offered correspondingly reduced. For the third period of 21 days fat was again included in the concentrate mixture, after which $\mathrm{S}_{3}$ was removed from experiment. In the fourth period of 21 days with $\mathrm{M}_{9} 8$ the fat was again omitted from the concentrate mixture, but the amount of mixture offered was increased by $5 \%$ to maintain the calorie intake and in a final period of 21 days the fat was again included.

Expt 2 was designed to study the effect on milk fat of additions of coconut oil, red palm oil or groundnut oil to a basal diet of meadow hay ( $5 \mathrm{~kg})$, sugar-beet pulp $(5 \mathrm{~kg})$ and a concentrate mixture $(8 \mathrm{~kg})$ consisting of barley $(2 \mathrm{r} \cdot 8 \%)$, rice $(\mathrm{I} 6.3 \%)$, tapioca $(16.3 \%)$, decorticated groundnut meal $(32.7 \%)$, blood meal (10.9\%), minerals $(2 \cdot 0 \%)$. The oils were added to the concentrate mixture at the rate of $0.3 \mathrm{~kg} / \mathrm{day}$. The fat (ether extract) content of the hay was $0.9 \%$, of the sugar-beet pulp $0.4 \%$ and of the concentrate mixture before addition of the fat $0.5 \%$. The total daily intake of fat on the unsupplemented ration was $100 \mathrm{~g}$. The design was a $4 \times 4$ Latin square balanced with respect to residual effects and the periods were of 14 days.

Sampling. Milk yield was recorded and samples of milk were taken at each milking. Composite samples representing 4-day periods were prepared, with the exception of samples representing a single day at the beginning of each $2 \mathrm{I}$-day period in Expt $\mathrm{I}$ and of samples representing 2 days at the beginning of each 14 -day period on Expt 2. The fat content of the milk was measured by the Gerber method (British Standards Institution, 1955).

On certain days throughout Expt I samples of blood were taken through an indwelling cannula, inserted in the jugular vein before the start of the experiment, at $09.00,12.00$ and $15.00 \mathrm{~h}$.

Analysis of milk fat. Fat was extracted from milk in chloroform-methanol (2: I, 
$\mathrm{v} / \mathrm{v}$ ) as fully described elsewhere (Storry \& Millard, 1965). Methyl esters of the fatty acids were prepared in sealed tubes according to the basic procedure of delMan (1964), but the following modifications were found necessary to ensure complete transesterification. A portion of the chloroform-methanol extract containing $40 \mathrm{mg}$ fat was pipetted into a freeze-drying tube and the solvent evaporated under nitrogen. To the fat in the tube was added $\mathrm{I} \mathrm{ml}$ of $0.025 \mathrm{~N}$-sodium methoxide (prepared by dissolving sodium metal in anhydrous methanol) and the tube was then sealed and heated in an oven at $100^{\circ}$ for $\mathrm{I} \mathrm{h}$. The higher temperature and the modified ratio of fat to sodium methoxide were found necessary for the transesterification reaction to go to completion and were arrived at after extensive investigation, using thin-layer chromatography to examine the reaction mixtures, of the conditions described by deMan (1964), which in our hands did not prove to be satisfactory.

The complete mixture of methyl esters of the milk fatty acids was then analysed on a Perkin-Elmer model F I I gas chromatograph fitted with a single column and a flame ionization detector. Columns $2 \mathrm{~m}$ in length and $\frac{1}{8}$ in. in diameter were packed with polyethylene glycol adipate on acid- and alkali-washed celite of 100-120 mesh grade in the proportion by weight of 20:80. Atpet 80 (Perkin Elmer Ltd, Beaconsfield, Bucks.) was also added to the stationary phase to facilitate uniform coating of the support and to inhibit tailing of the acids on the chromatogram. The Atpet 80 was subsequently scrubbed from the column during the period of initial conditioning.

Columns were conditioned for $48 \mathrm{~h}$ at a temperature of $200^{\circ}$ and a gas flow rate of $60 \mathrm{ml} / \mathrm{min}$. The column was operated for an initial period of $3 \mathrm{~min}$ at $75^{\circ}$ and the temperature then increased at a rate of $8^{\circ} / \mathrm{min}$ to a final temperature of $\mathrm{I} 80^{\circ}$. The carrier gas flow rate was $55 \mathrm{ml} / \mathrm{min}$. The ancillary gases to the detector were controlled by 2 -stage regulators and restrictors in the gas lines, the inlet pressures for hydrogen and air being 15 and $25 \mathrm{lb} / \mathrm{in}^{2}$ respectively.

The sealed tube containing the esterification mixture was broken and a $2 \mu \mathrm{l}$ sample of the contents was immediately injected, with a Hamilton syringe, into the injection block maintained at a temperature of approximately $25^{\circ}$. Peaks were identified by comparison with authentic esters and by relative retention times. Quantification of the peaks was made with a disc integrator (Disc Instruments Inc., Santa Ana, California, USA). The values obtained were converted into weight percentages, using detector response factors obtained with authentic ester standards for acids with less than ten carbon atoms. For acids with carbon chains of more than ten atoms the response of area percentage equalled that of weight percentage. This simplified method gave closely reproducible results which compared favourably with the laborious methods previously used in this laboratory (Storry \& Rook, I965) in which the lower fatty acids were separated by steam distillation and determined by gas-liquid chromatography on a separate column. The loss of the lower volatile methyl esters was avoided by carrying out the reaction in sealed tubes.

Analysis of blood. The plasma from the various samples taken was analysed for glucose (Huggett \& Nixon, 1957), ketone bodies (Reid, I960), steam-volatile fatty acids (Scarisbrick, 1952), non-esterified fatty acids (Annison, 1960) and plasma lipids (Storry \& Rook, 1965). The steam-volatile fatty acids were further fractionated by 
gas-liquid chromatography (Storry \& Millard, 1965). The triglyceride fractions of the plasma lipids obtained by column chromatography were rechromatographed on thin-layer plates of silicic acid with a solvent mixture of hexane, diethyl ether and glacial acetic acid in the ratio $85: 15: 1$ to ensure that the triglyceride fraction was pure. The fatty acid composition was then determined by gas chromatography according to the procedure used for milk fat. As only $0.5 \mathrm{mg}$ of plasma triglyceride was available for fatty acid analysis the transesterification reaction was carried out in sealed glass tubes measuring $10 \times 0.5 \mathrm{~mm}$ with a ratio of triglyceride to sodium methoxide of $\mathrm{x}: 40$.
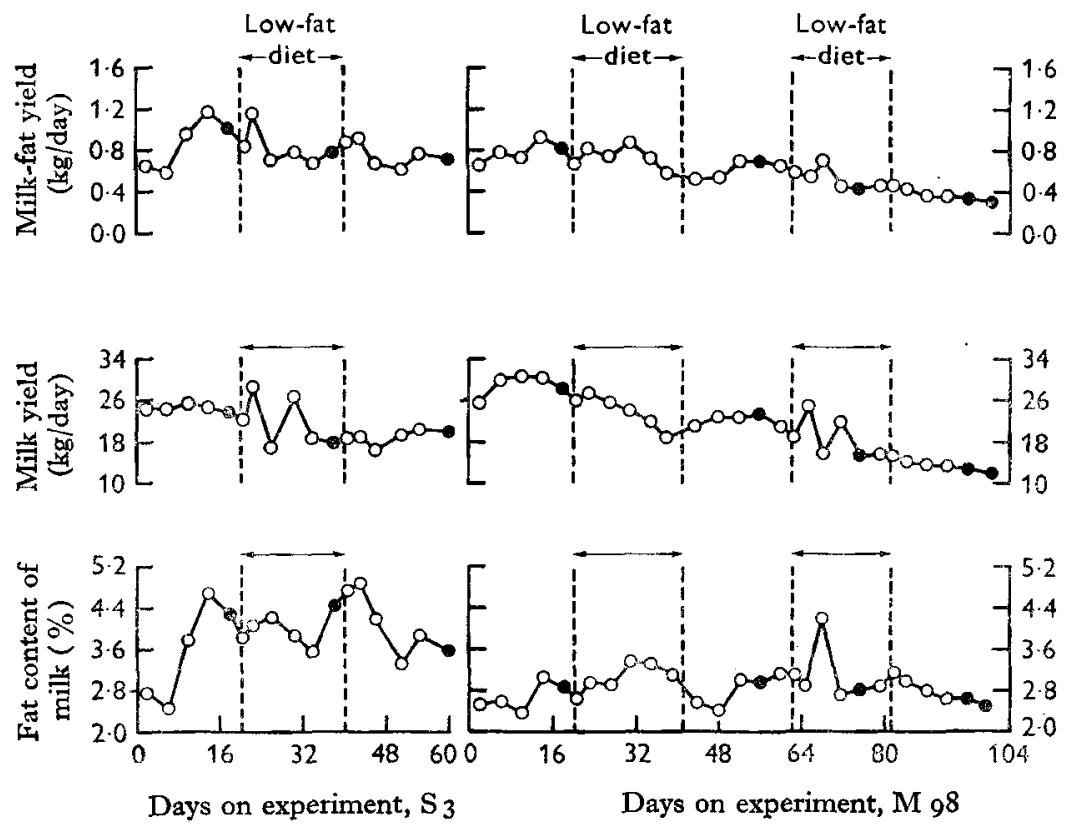

Fig. I. Effect in cows $\mathrm{S}_{3}$ and $\mathrm{Mg}_{9} 8$ of the omission of the fat supplement from the diet (lowfat diet) on the yield of milk and milk fat, and on the fat content of the milk. $\bullet$, samples used for determination of fatty acid composition.

\section{RESULTS}

\section{Experiment I}

Effect of removal of a dietary fat supplement on the yields of milk and milk fat and on the composition of milk fat. The effects of removing a fat supplement from the diet on milk yield, yield of milk fat and on milk fat content are shown in Fig. I. In both cows there was a progressive decline in milk yield following the normal lactational pattern and there appeared to be no effect of dietary fat except that during periods" of low-fat intake milk yields were more variable. Similarly, the yield of milk fat declined progressively throughout the experiment and was not significantly affected by the removal of the fat supplement from the diet. On average the fat content of the milk from both cows was higher during periods of low fat intake but within any one period the 
variation in fat content was so large that the differences between periods were not significant.

The dietary intake of fatty acids on the basal and fat-supplemented diets are given in Table $\mathrm{r}$. Withdrawal of the fat supplement decreased the daily fat intake from about 410 to $160 \mathrm{~g}$ for $\mathrm{S}_{3}$ and from about 460 to $180 \mathrm{~g}$ for $\mathrm{M}_{98}$; this was associated with reduced intakes of capric, lauric, myristic, palmitic, stearic, oleic and linoleic acids, which were the major component acids of the fat supplement.

The fatty acid composition of the penultimate or the last 4 -day composite milk

Table I. Expt I. Daily intake of the major fatty acids by cows $S_{3}$ and $M 98$ on fat-supplemented and unsupplemented diets

\begin{tabular}{|c|c|c|c|c|}
\hline \multirow[b]{3}{*}{ Fatty acid* } & \multicolumn{4}{|c|}{ Intake (g/day) } \\
\hline & \multicolumn{2}{|c|}{ Cow $S_{3}$} & \multicolumn{2}{|c|}{ Cow $\mathrm{M}_{98}$} \\
\hline & $\begin{array}{c}\text { Low-fat } \\
\text { diet }\end{array}$ & $\begin{array}{c}\text { High-fat } \\
\text { diet }\end{array}$ & $\begin{array}{c}\text { Low-fat } \\
\text { diet }\end{array}$ & $\begin{array}{c}\text { High-fat } \\
\text { diet }\end{array}$ \\
\hline I0:0 & $4 \cdot 2$ & 10.7 & $4 \cdot 4$ & II 7 \\
\hline $12: 0$ & 3.5 & 85.7 & 3.8 & $96 \cdot 3$ \\
\hline $14: 0$ & $2 \cdot 6$ & $35 \cdot 8$ & $2 \cdot 9$ & $40 \cdot 0$ \\
\hline $16: 0$ & $39 \cdot 3$ & $8 \mathrm{r} \cdot 9$ & $3^{8 \cdot 6}$ & 89.5 \\
\hline 18:0 & $12 \cdot 5$ & $48 \cdot 6$ & $13 \cdot 4$ & $54 \cdot \mathrm{I}$ \\
\hline I8: $\mathrm{I}$ & $47 \cdot 8$ & $86 \cdot 0$ & $5 \times 7$ & $94 \cdot 6$ \\
\hline $18: 2$ & 15.8 & $23 \cdot 2$ & 16.6 & $26 \cdot 0$ \\
\hline $18: 3$ & $3 \cdot 9$ & $2 \cdot 2$ & 4.2 & $2 \cdot 6$ \\
\hline $20: 0$ & $3 \cdot 3$ & $3 \cdot 3$ & $3 \cdot 3$ & $3 \cdot 3$ \\
\hline
\end{tabular}

* Number of carbon atoms and number of double bonds (Farquhar, Insull, Rosen, Stoffel \& Ahrens, 1959).

Table 2. Expt $\mathbf{1}$. Effect of dietary fat on the fatty acid composition of milk fat from cows $S_{3}$ and $M_{98}$

(Values represent the mean composition of samples taken at the end of each experimental period (see Fig. r))

\begin{tabular}{|c|c|c|c|c|}
\hline \multirow[b]{3}{*}{ Fatty acid* } & \multicolumn{4}{|c|}{ Content in milk fat $(\mathrm{g} / \mathrm{x} 00 \mathrm{~g})$} \\
\hline & \multicolumn{2}{|c|}{ Cow $\mathrm{S}_{3}$} & \multicolumn{2}{|c|}{ Cow $\mathrm{M} 98$} \\
\hline & $\begin{array}{c}\text { Low-fat } \\
\text { diet }\end{array}$ & $\begin{array}{l}\text { High-fat } \\
\text { diet }\end{array}$ & $\begin{array}{c}\text { Low-fat } \\
\text { diet }\end{array}$ & $\begin{array}{l}\text { High-fat } \\
\text { diet }\end{array}$ \\
\hline $4: 0$ & $2 \cdot 7$ & $2 \cdot 9$ & $2 \cdot 7$ & 2.7 \\
\hline $6: 0$ & $2 \cdot 0$ & $2 \cdot I$ & $1 \cdot 7$ & $x \cdot 6$ \\
\hline $8: 0$ & $I \cdot 2$ & $I \cdot 3$ & $I \cdot I$ & $I \cdot O$ \\
\hline 10:0 & $4 \cdot 2$ & $3 \cdot 8$ & $2 \cdot 9$ & $2 \cdot 7$ \\
\hline 12:0 & $5 \cdot 9$ & $7^{-6}$ & $4 \cdot 6$ & $6 \cdot I$ \\
\hline I $4: 0$ & 15.4 & $16 \cdot 3$ & 14.7 & ${ }^{5} \cdot \mathrm{I}$ \\
\hline I4:I & $I \cdot 9$ & $2 \cdot 4$ & 277 & $2 \cdot 4$ \\
\hline $16: 0$ & $42 \cdot x$ & $33 \cdot 5$ & $40 \% 7$ & $31 \cdot 5$ \\
\hline $16: 1$ & $3 \cdot 0$ & $2 \cdot 6$ & $5 \cdot 2$ & $4^{\circ} \circ$ \\
\hline 18:0 & $3 \cdot 4$ & $4 \cdot 9$ & $2 \cdot 3$ & $4 \cdot 7$ \\
\hline 18: I & $12 \cdot 2$ & $16 \cdot 8$ & 14.4 & $2 \pi \cdot 8$ \\
\hline $18: 2$ & 0.6 & 0.7 & 1.0 & $I \cdot 2$ \\
\hline
\end{tabular}

* See footnote to Table $\mathrm{r}$. In addition to the fatty acids given, there were small concentrations of a number of fatty acids tentatively identified as $10: I_{1}, 11: 0,12: 1, r_{3}: 0 \mathrm{br}, 13: 0,14: 0 \mathrm{br}, 15: 0 \mathrm{br}$, I 5:0, 16:0 br, 17:० br, 17:0, I8:० br, amounting to about $5 \%$ of the milk fat. 
sample from each experimental period was determined, and the mean values for each of the two cows during periods of high and low dietary fat intake are given in Table 2. The yields of the major acids in the milk fat are given in Table 3 . Withdrawal of fat from the diet was associated with decreased proportions and yields of lauric, myristic, stearic, oleic and linoleic acids in the milk fat. In spite of the reduced dietary intake

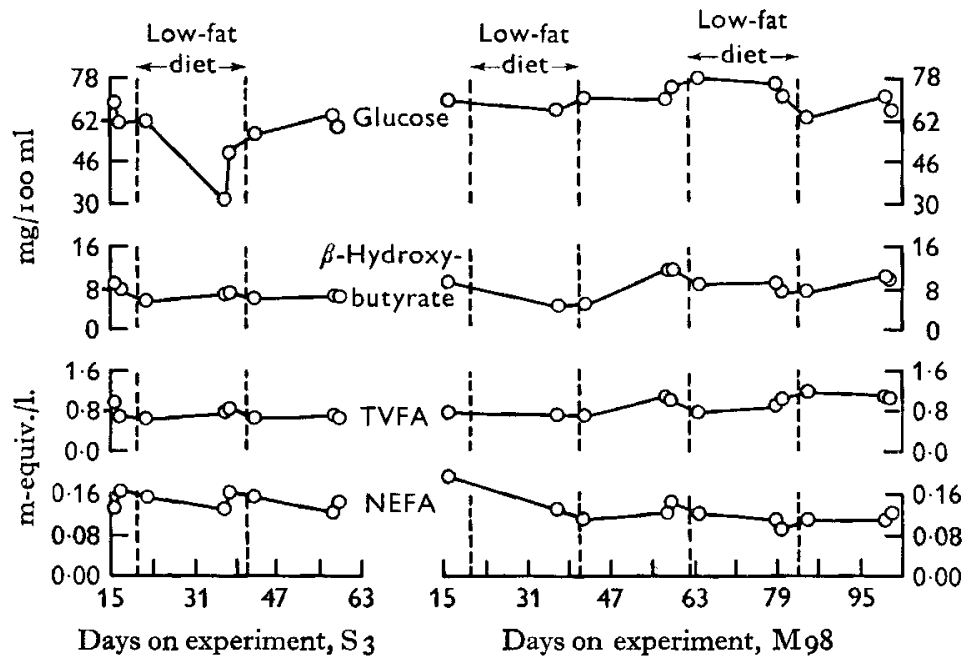

Fig. 2. Effect in cows $\mathrm{S}_{3}$ and $\mathrm{M}_{9} 8$ of the omission of the fat supplement from the diet on the concentration in plasma of glucose, $\beta$-hydroxybutyrate, total volatile fatty acids and nonesterified fatty acids.

Table 3. Expt 1. Effect of dietary fat on the yields of the major fatty acids of milk fat for cows $S_{3}$ and $M 98$

(Values are the means for all samples taken at the end of each experimental period (see Fig. I))

\begin{tabular}{|c|c|c|c|c|}
\hline \multirow[b]{3}{*}{ Fatty-acid* } & \multicolumn{4}{|c|}{ Fatty acid yield (g/day) } \\
\hline & \multicolumn{2}{|c|}{ Cow $\mathrm{S}_{3}$} & \multicolumn{2}{|c|}{ Cow $\mathrm{Mg}_{98}$} \\
\hline & $\begin{array}{c}\text { Low-fat } \\
\text { diet }\end{array}$ & $\begin{array}{l}\text { High-fat } \\
\text { diet }\end{array}$ & $\begin{array}{c}\text { Low-fat } \\
\text { diet }\end{array}$ & $\begin{array}{l}\text { High-fat } \\
\text { diet }\end{array}$ \\
\hline $4: 0$ & $19 \cdot 6$ & $22 \cdot 8$ & 10.9 & I3.4 \\
\hline $6: 0$ & 14.5 & $16 \cdot 5$ & $6 \cdot 8$ & 7.9 \\
\hline $8: 0$ & $8 \cdot 7$ & $10 \cdot 2$ & $4 \cdot 4$ & $5 \cdot 0$ \\
\hline $10: 0$ & 30.5 & 29.9 & II'7 & 13.4 \\
\hline $12: 0$ & $42 \cdot 9$ & $59 \cdot 7$ & $18 \cdot 5$ & $30 \cdot 3$ \\
\hline $14: 0$ & III-9 & I $28 \cdot I$ & 59.1 & 74.9 \\
\hline $16: 0$ & 305.9 & $263 \cdot 3$ & 163.7 & I $56 \cdot 3$ \\
\hline 18:0 & 24.7 & $38 \cdot 5$ & $9 \cdot 3$ & $23 \cdot 3$ \\
\hline I8:I & $88 \cdot 7$ & $132 \cdot I$ & 57.9 & $108 \cdot 2$ \\
\hline $18: 2$ & $4 \cdot 4$ & $5 \cdot 5$ & 4.0 & $6 \cdot 0$ \\
\hline
\end{tabular}

of palmitic acid when the fat supplement was omitted from the diet the proportion and yield of this acid in the milk fat increased. The yields of butyric, caproic, capryllic and capric acids tended to be higher when the fat supplement was given. 
Effect of removal of the dietary fat supplement on blood composition. There was no effect of dietary fat on the concentrations in plasma of glucose, $\beta$-hydroxybutyrate, total volatile fatty acid or non-esterified fatty acid (Fig. 2), and the proportions of the individual volatile fatty acids also were unaffected. In both cows the concentrations in the plasma of total lipid, phospholipid, cholesterol ester, free cholesterol, and in one cow $\left(\mathbf{S}_{3}\right)$ also of triglyceride, were consistently reduced on the low-fat diet (Fig. 3 ). The mean fatty acid composition of the plasma triglycerides for samples taken on the last, or sometimes the last 2, days of each experimental period are given in Table 4 . The omission of the fat supplement from the diet was associated with considerable

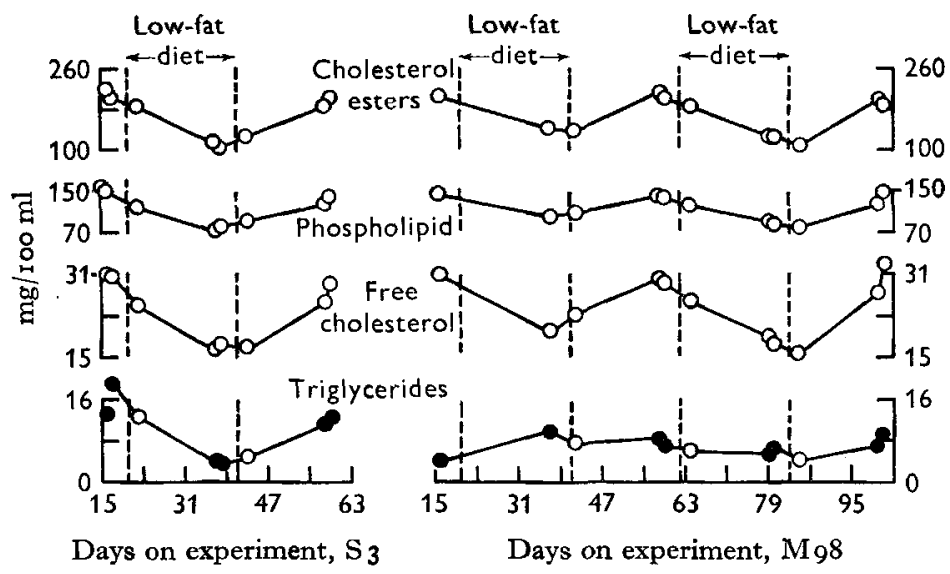

Fig. 3. Effect in cows $\mathrm{S}_{3}$ and $\mathrm{M} 98$ of the omission of the fat supplement from the diet on the concentration in plasma of phospholipid, esterified cholesterol, free cholesterol and triglycerides. , samples used for the determination of fatty acid composition.

Table 4. Expt I. Effect of dietary fat on the fatty acid composition of plasma triglycerides in cows $S_{3}$ and $M_{98}$

(Values are the means for samples taken at the end of each experimental period (see Fig. 3))

\begin{tabular}{|c|c|c|c|c|}
\hline \multirow[b]{3}{*}{ Fatty acid* } & \multicolumn{4}{|c|}{ Content in plasma triglycerides $(\mathrm{g} / \mathrm{1} 00 \mathrm{~g})$} \\
\hline & \multicolumn{2}{|c|}{ Cow $\mathrm{S}_{3}$} & \multicolumn{2}{|c|}{ Cow M98 } \\
\hline & $\begin{array}{c}\text { Low-fat } \\
\text { diet }\end{array}$ & $\begin{array}{c}\text { High-fat } \\
\text { diet }\end{array}$ & $\begin{array}{c}\text { Low-fat } \\
\text { diet }\end{array}$ & $\begin{array}{l}\text { High-fat } \\
\text { diet }\end{array}$ \\
\hline $12: 0$ & 0.3 & $5 \cdot 4$ & 0.5 & $5 \cdot I$ \\
\hline $14: 0$ & $3 \cdot 0$ & $6 \cdot 7$ & $2 \cdot 9$ & $8 \cdot 0$ \\
\hline I $5: 0 \mathrm{br}$ & $2 \cdot 2$ & $I \cdot 8$ & $I \cdot 9$ & $\mathrm{I} \cdot 6$ \\
\hline I5:0 & $2 \cdot 4$ & $I \cdot 6$ & 2.4 & $\mathrm{r} \cdot 6$ \\
\hline $16: 0$ & $28 \cdot 8$ & $25 \cdot 6$ & $3 I \cdot 3$ & $27 \cdot 3$ \\
\hline $16: 1$ & $4 \cdot 2$ & $I \cdot 9$ & $3 \cdot 2$ & $2 \cdot 7$ \\
\hline I7:0 br & $I \cdot 6$ & $\mathrm{I} \cdot 3$ & $1 \cdot 6$ & $2 \cdot 4$ \\
\hline I7:0 & $4 \cdot 2$ & $I \cdot 9$ & $2 \cdot 5$ & $I \cdot 7$ \\
\hline I $8: 0$ & $32 \cdot 8$ & $37 \cdot 9$ & $29 \cdot 0$ & $3 \mathrm{r} \cdot 5$ \\
\hline $18: 1$ & $15 \cdot 1$ & 1377 & 19.0 & $16 \cdot 9$ \\
\hline I8:2 & $3 \cdot 2$ & $2 \cdot 0$ & $3 \cdot 8$ & 0.7 \\
\hline
\end{tabular}

* See footnote to Table 1 . In addition to the fatty acids given traces of $12: 1,13: 0,14: 1,16: 0$ br and r: 0 br acids were found. 
reductions in the proportions of lauric and myristic acids, with a smaller reduction in the proportion of stearic acid, and with increased proportions of palmitic, oleic and linoleic acids. In terms of the concentrations of the individual acids of the plasma triglycerides (Table 5) the omission of the fat supplement from the diet reduced the concentrations in both cows of lauric and myristic acids and also, in one cow $\left(\mathrm{S}_{3}\right)$ only, of palmitic, stearic, oleic and linoleic acids.

Table 5. Expt I. Effect of dietary fat on the concentration in plasma of the major triglyceride fatty acids for cows $S_{3}$ and $M_{9} 8$

(Values are the means for samples taken at the end of each experimental period (see Fig. 3))

\begin{tabular}{|c|c|c|c|c|}
\hline \multirow[b]{3}{*}{ Fatty acid* } & \multicolumn{4}{|c|}{ Concentration in plasma $(\mathrm{mg} / \mathrm{roo} \mathrm{ml})$} \\
\hline & \multicolumn{2}{|c|}{ Cow $\mathrm{S}_{3}$} & \multicolumn{2}{|c|}{ Cow M98 } \\
\hline & $\begin{array}{c}\text { Low-fat } \\
\text { diet }\end{array}$ & $\begin{array}{l}\text { High-fat } \\
\text { diet }\end{array}$ & $\begin{array}{c}\text { Low-fat } \\
\text { diet }\end{array}$ & $\begin{array}{l}\text { High-fat } \\
\text { diet }\end{array}$ \\
\hline I2:0 & 0.01 & 0.76 & 0.04 & 0.35 \\
\hline I 4:0 & O.II I & 0.94 & 0.22 & 0.53 \\
\hline I $5: 0 \mathrm{br}$ & 0.08 & 0.26 & 0.15 & 0.09 \\
\hline I5:0 & 0.09 & 0.23 & 0.18 & 0.10 \\
\hline $16: 0$ & $\mathrm{I} \cdot 05$ & $3 \cdot 58$ & $2 \cdot 43$ & $\mathrm{I} \cdot 78$ \\
\hline I6: I & 0.15 & 0.27 & 0.25 & 0.17 \\
\hline $17: 0 \mathrm{br}$ & 0.06 & $0 \cdot 18$ & 0.12 & 0.12 \\
\hline I7:0 & 0.15 & 0.27 & 0.19 & 0.11 \\
\hline $18: 0$ & $I \cdot 18$ & $5 \cdot 18$ & $2 \cdot 19$ & $2 \cdot 04$ \\
\hline I 8: I & 0.54 & $\mathrm{I} \cdot 84$ & $I \cdot 5 I$ & $r \cdot 06$ \\
\hline $18: 2$ & 0.12 & 0.28 & 0.30 & 0.05 \\
\hline
\end{tabular}

\section{Experiment 2}

Effect of coconut, red palm and groundnut oil supplements to the diet on the yield of milk and milk fat and on the composition of milk fat. The basal diet of hay, sugar-beet pulp and concentrate mixture in this experiment provided a total daily fat intake of $105 \mathrm{~g}$ during the control period and the diets supplemented with coconut, red palm or groundnut oil gave daily intakes of 379,455 and $379 \mathrm{~g}$ respectively. The intakes of fatty acids for the four diets are given in Table 6 . The coconut oil supplement increased the intake of capric, lauric, myristic, palmitic, stearic and oleic acids, the red palm oil the intake of palmitic, stearic, oleic and linoleic acids, and the groundnut oil the intake of palmitic, stearic, oleic, linoleic, linolenic and arachidonic acids.

In assessing the effects of the various diets on the yield of milk and on the composition and yield of milk fat, the values obtained during the last 8 days of each $\mathbf{r} 4$-day experimental period were used to avoid any carry-over effect from one diet to the next. Statistical analysis of the results obtained from the Latin square design allowed critical evaluation of the effects of the dietary fat supplements since variation due to differences between animals and stage of lactation could be assessed. The effects of the fat supplements on the yield of milk, and on the yield and content of milk fat are given, as a mean for the four animals, in Table 7. Although the yield of milk tended to be higher with all oil supplements, only with groundnut oil was the increase signi- 
ficant $(P<0.05)$. The fat content of the milk was significantly increased by coconut oil and red palm oil $(P<0.001)$, but not by groundnut oil; all three oils significantly increased the yield of milk fat (Table 7$)$.

Table 6. Expt 2. Daily intake by the cows of the major fatty acids with the basal and various oil-supplemented diets

\begin{tabular}{|c|c|c|c|c|}
\hline \multirow[b]{2}{*}{ Fatty acid* } & \multicolumn{4}{|c|}{ Intake (g/day) } \\
\hline & $\begin{array}{c}\text { Basal } \\
\text { diet }\end{array}$ & $\begin{array}{l}\text { Coconut } \\
\text { oil diet }\end{array}$ & $\begin{array}{l}\text { Red palm } \\
\text { oil diet }\end{array}$ & $\begin{array}{l}\text { Groundnut } \\
\text { oil diet }\end{array}$ \\
\hline IO:O & - & $9 \cdot x$ & - & - \\
\hline $12: 0$ & $2 \cdot 6$ & 130.0 & $I \cdot 4$ & $I \cdot 9$ \\
\hline 1 4:0 & $I \cdot 7$ & $57 \cdot 9$ & $2 \cdot 2$ & $2 \cdot 0$ \\
\hline 16:0 & $32 \cdot 2$ & 63.4 & $179^{\circ} I$ & 64.7 \\
\hline 17:0 & $2 \cdot 1$ & $3 \cdot I$ & $2 \cdot 9$ & $3 \cdot 7$ \\
\hline $18: 0$ & $9 \cdot 3$ & $43 \cdot 5$ & $29 \cdot 9$ & $19 \cdot 1$ \\
\hline I 8: I & 19.1 & $28 \cdot 5$ & 164.7 & $169 \cdot 3$ \\
\hline $18: 2$ & $23 \cdot 6$ & $28 \cdot 2$ & $61 \cdot \mathrm{I}$ & $92 \cdot 6$ \\
\hline $18: 3$ & $I \cdot O$ & $I \cdot O$ & $I \cdot O$ & $8 \cdot 2$ \\
\hline $20: 0$ & $2 \cdot 4$ & $2 \cdot 4$ & $2 \cdot 4$ & $6 \cdot 7$ \\
\hline $20: 1$ & $4 \cdot 8$ & $4 \cdot 8$ & $4 \cdot 8$ & $4 \cdot 8$ \\
\hline $20: 2$ & I.9 & $I \cdot 9$ & I.9 9 & $I \cdot 9$ \\
\hline $20: 3$ & $2 \cdot 0$ & $2 \cdot 0$ & $2 \cdot 0$ & $2 \cdot 0$ \\
\hline
\end{tabular}

Table 7. Expt 2. Effect of coconut, red palm and groundnut oil supplements to the diet on the percentage and yield of milk fat and on the yield of milk

(Values are the means for samples taken from four cows during the last 8 days of each $\mathbf{1} 4$-day experimental period)

$\begin{array}{lccc}\begin{array}{c}\text { Supplement to } \\ \text { basal diet }\end{array} & \begin{array}{c}\text { Milk } \\ \text { yield } \\ (\mathrm{kg} / \mathrm{day})\end{array} & \begin{array}{c}\text { Milk fat } \\ \text { content } \\ (\%)\end{array} & \begin{array}{c}\text { Yield of } \\ \text { milk fat } \\ \text { (g/day) }\end{array} \\ \text { None } & 16.03 & 3.63 & 581 \\ \text { Coconut oil } & 16.72 & 3.97^{* * *} & 675^{* *} \\ \text { Red palm oil } & 17.52 & 3.99^{* * *} & 689^{* *} \\ \text { Groundnut oil } & 18.39^{*} & 3.57 & 657^{*}\end{array}$

* $\mathrm{P}<0.05$; ** $P<0.01$; *** $P<0.001$, where $P$ is the probability that the observed difference from the control value could have arisen by chance.

The effects of the various supplements on the fatty acid composition and on the yields of the major fatty acids in the milk fat are given in Tables 8 and 9 respectively. The coconut oil significantly increased the proportions of lauric and myristic acids and decreased those of palmitic and linoleic acids. The proportion of oleic acid was also increased, but not significantly. The yields of all the major acids except linoleic acid, which was significantly decreased, were increased with the coconut oil supplement, but only the increased yields of butyric, lauric, myristic and stearic were significant.

Red palm oil significantly increased the proportion of stearic acid and decreased the proportions of capric, lauric, myristic and linoleic acids. The proportions of palmitic and oleic acids tended to be decreased and increased respectively, but neither change reached significance. Red palm oil significantly increased the yields of butyric, stearic and oleic acids. The yield of palmitic acid was also increased, but not significantly. 
Groundnut oil significantly increased the proportions of stearic and oleic acids and decreased significantly those of lauric, palmitic and palmitoleic acids, whereas the yields of butyric, myristic, stearic and oleic were all significantly increased. Also the yields of caproic, capryllic and capric acids tended to be increased and those of lauric and palmitic acids decreased by the groundnut oil, but these changes were not significant.

\section{Table 8. Expt 2. Effect of coconut, red palm and groundnut oil supplements to the diet on the fatty acid composition of milk fat}

(Values are the means for samples taken from four cows during the last 8 days of each I 4 -day experimental period)

\begin{tabular}{|c|c|c|c|c|}
\hline \multirow[b]{2}{*}{$\begin{array}{l}\text { Fatty } \\
\text { acidt }\end{array}$} & \multicolumn{4}{|c|}{ Content in milk fat $(\mathrm{g} / \mathrm{r} 00 \mathrm{~g})$} \\
\hline & $\begin{array}{l}\text { Control } \\
\text { diet }\end{array}$ & $\begin{array}{l}\text { Coconut } \\
\text { oil diet }\end{array}$ & $\begin{array}{l}\text { Red palm } \\
\text { oil diet }\end{array}$ & $\begin{array}{l}\text { Groundnut } \\
\text { oil diet }\end{array}$ \\
\hline $4: 0$ & $2 \cdot 8$ & $2 \cdot 8$ & $3 \cdot 0$ & $3 \cdot 2$ \\
\hline $6: 0$ & $I \cdot 9$ & $I \cdot 9$ & $\pm \cdot 8$ & $2 \cdot 2$ \\
\hline $8: 0$ & $I \cdot 3$ & $1 \cdot 3$ & $I \cdot 2$ & $\mathrm{I} \cdot 4$ \\
\hline IO:O & $3 \cdot 9$ & $3 \cdot 8$ & $3 \cdot 1^{* * *}$ & $3 \cdot 8$ \\
\hline I2:0 & $6 \cdot 2$ & ro.2*** & $4 \cdot 4^{* *}$ & $5 \cdot 2 *$ \\
\hline $14: 0$ & $15 \cdot 7$ & $18 \cdot 4 * * *$ & $13 \cdot 2 * * *$ & 15.0 \\
\hline $14: I$ & $2 \cdot 4$ & $2 \cdot 8$ & $2 \cdot 8$ & $2 \cdot 0$ \\
\hline I $5: 0$ & $\mathrm{I} \cdot 5$ & $I \cdot I$ & 0.9 & $\mathbf{I} \cdot \mathbf{I}$ \\
\hline I6:0 & $39 \cdot 6$ & $34 \cdot 0 * *$ & $37 \cdot 0$ & $29 \cdot 6 * * *$ \\
\hline I6: I & 37 & 3.6 & $3 \cdot 4$ & $2 \cdot 4 * * *$ \\
\hline ז8:0 & $2 \cdot 8$ & $2 \cdot 5$ & $5 \cdot 6 * * *$ & $7 \cdot 2 * * *$ \\
\hline 18:1 & $12 \cdot 7$ & 14.9 & $18 \cdot 6$ & $22 \cdot 2 *$ \\
\hline $18: 2$ & $1 \cdot 3$ & $0.4 * * *$ & $0.9 *$ & $1 \cdot 2$ \\
\hline
\end{tabular}

* $P<0.05$; ** $P<0.01$; *** $P<0.001$; where $P$ is the probability that the observed difference from the control value could have arisen by chance.

$\dagger$ See footnote to Table $\mathrm{r}$. In addition to the fatty acids given, there were small concentrations of a number of fatty acids tentatively identified as $10: \mathrm{I}, \mathrm{II}: 0,12: \mathrm{I}, 13: 0,14: 0 \mathrm{br}, 15.0 \mathrm{br}, 16: 0 \mathrm{br}, 17: 0 \mathrm{br}$, 17:0, 18:0 br acids, amounting to about $5 \%$ of the milk fat.

\section{Table 9. Expt 2. Effect of coconut, red palm and groundnut oil supplements} to the diet on the yields of the major fatty acids in milk

(Values are the means for samples taken from four cows during the last 8 days of each $\mathrm{I}_{4}$-day experimental period)

\begin{tabular}{|c|c|c|c|c|}
\hline \multirow[b]{2}{*}{$\begin{array}{l}\text { Fatty } \\
\text { acid } \dagger\end{array}$} & \multicolumn{4}{|c|}{ Yield (g/day) } \\
\hline & $\begin{array}{c}\text { Control } \\
\text { diet }\end{array}$ & $\begin{array}{l}\text { Coconut } \\
\text { oil diet }\end{array}$ & $\begin{array}{l}\text { Red palm } \\
\text { oil diet }\end{array}$ & $\begin{array}{l}\text { Groundnut } \\
\text { oil diet }\end{array}$ \\
\hline $4: 0$ & 14.9 & $18 \cdot 3^{*}$ & I $8 \cdot 9^{*}$ & I $8.8 *$ \\
\hline $6: 0$ & II. 3 & $\begin{array}{r}14.0 \\
8.4\end{array}$ & $\begin{array}{r}13 \cdot 5 \\
7 \cdot 8\end{array}$ & $\begin{array}{r}{ }^{1} \cdot 1 \\
8 \cdot 5\end{array}$ \\
\hline $8: 0$ & $\begin{array}{r}6.6 \\
20.5\end{array}$ & $\begin{array}{r}8.4 \\
23 \cdot 8\end{array}$ & $\begin{array}{r}7 \cdot 8 \\
19.6\end{array}$ & $\begin{array}{r}8.5 \\
22.4\end{array}$ \\
\hline $12: 0$ & $3 I \cdot 9$ & $69.1 * * *$ & $27 \cdot 3$ & $30 \cdot 2$ \\
\hline I 4:0 & $82 \cdot 5$ & $\operatorname{II} 4.9 * * *$ & $83 \cdot 6$ & $89 \cdot 1 *$ \\
\hline $16: 0$ & $211 \cdot 7$ & 215.6 & $233^{\prime 2}$ & I 78.8 \\
\hline I 8:0 & $14 \cdot 4$ & $2 I \cdot 9^{*}$ & $344^{* * *}$ & $44 \cdot 2 * * *$ \\
\hline I8:I & $67 \cdot 4$ & $77 \cdot 3$ & $130 \cdot 0 * *$ & $136 \cdot I * * *$ \\
\hline $18: 2$ & $6 \cdot 4$ & $2 \cdot 6 * *$ & $5 \cdot 2$ & $7 \cdot 3$ \\
\hline
\end{tabular}

* $P<0.05$; ** $P<0.01$; *** $P<0.001$; where $P$ is the probability that the observed difference from the control value could have arisen by chance.

+ See footnote to Table $\mathrm{I}$. 


\section{DISCUSSION}

The diets used in these experiments were readily accepted by the animals and they produced no obvious digestive or physiological disturbances. The basal concentrate mixtures used in both experiments, and particularly in the second, provided dietary fat intakes which were low compared with the intake from normal rations for milking cows.

The results obtained in the second experiment show that when the intake of dietary fat is sufficiently low, the lactating cow responds to the addition of extra fat in the diet by an increased total synthesis of milk fat. This was not observed in the first experiment, probably for two reasons. First, with only two animals, the changeover design used was inadequate to show up any response to added fat, which if present must have been small in relation to the day-to-day variation in the yield of milk fat. Secondly, the daily intake of dietary fat on the basal ration was of the order of $160-180 \mathrm{~g}$ in Expt $\mathrm{I}$, compared with an intake of only $105 \mathrm{~g}$ in Expt 2, and therefore may not have been sufficiently low to limit the synthesis of milk fat.

The reduced concentrations in plasma of phospholipid and free and esterified cholesterol in association with the removal of the fat supplement from the diet fully confirm the findings already cited in the literature. The fall in concentration of total plasma triglycerides in association with a reduced intake of dietary fat was observed in cow $\mathrm{S}_{3}$ for one period only and it is therefore difficult to assess what effect the intake of dietary fat has on the concentration of plasma triglyceride. Recently Hartmann, Harris \& Lascelles (1966) demonstrated that an oral dose of 480 g safflower oil to a lactating cow doubled the output of triglyceride in the thoracic lymph, but did not significantly increase the concentration of total triglycerides in the plasma because the chylomicra were rapidly cleared from the blood. However, in neither our experiments nor those of Hartmann et al. (I966) were the plasma triglycerides separated into the separate lipoproteins, and it is possible that the concentration of the low-density lipoproteins, which have an important role in milk fat synthesis, may be more sensitive than the total plasma triglycerides to changes in the level of dietary fat. It is clear, however, that the composition and concentration of the fatty acids in the plasma triglycerides were influenced by the amount and type of fat in the diet. In both cows the increased dietary intake of lauric and myristic acids was associated with increased proportions and concentrations of these acids in the plasma triglycerides and also, in cow $\mathrm{S}_{3}$, increased intakes of palmitic, stearic, oleic and linoleic acids were associated with increased concentrations of these acids in the plasma.

The results of both experiments show that dietary fat influences the composition and yield of fatty acids in milk fat. The increased proportions and yields of lauric and myristic acids in milk fat associated with the supplement of coconut oil in both experiments support the findings of earlier workers that coconut oil increases the lauric and myristic acid content of milk (Holland, Garvey, Pierce, Messer, Archibald \& Dunbar, 1923; Hilditch \& Sleightholme, 1930; Mohammed, Brown, Riley \& Stull, 1964) and this effect is mediated through the plasma triglycerides. The diets supplemented with red palm or groundnut oil were associated with large dietary intakes of the $\mathrm{C}_{\mathrm{I}} 8$ acids, 
particularly the oleic and linoleic acids, and the yields of stearic and oleic, but not of linoleic, acids in the milk fat were markedly increased. The lack of an appreciable increase in the yield or content of linoleic acid, in spite of an increased dietary intake of this acid, confirms similar observations following feeding with cottonseed oil (Brown, Stull \& Stott, I962), soya-bean oil (Tove \& Mochrie, I963) and safflower oil (Parry, Sampugna \& Jensen, 1964), and is no doubt accounted for by hydrogenation of the linoleic acid to oleic and stearic acids by micro-organisms in the rumen (Garton, 1960, 1965).

The present experiments have brought to light the fact that palmitic acid appears to behave differently from the other acids in milk fat. In both experiments the dietary intake of palmitic acid was substantially increased by the addition of fat to the diet, and yet the content and yield of this acid in the milk fat was not significantly increased and indeed sometimes it was decreased. According to Barry (1964) the acids in milk fat with a carbon chain of intermediate length (i.e. $\mathrm{C}_{I 2}-\mathrm{C}_{\mathrm{I}} 6$ ) are thought to be synthesized partly from acetate and also derived partly from palmitic acid in the plasma triglycerides. The lack of an increased yield of palmitic acid in the milk in association with an increased dietary intake of this acid is thus difficult to explain, especially when a response in the yields of lauric and myristic acids was obtained with the supplement of coconut oil. In view of the established uptake by the mammary gland of palmitic acid from the low-density lipoprotein triglycerides of plasma (Barry et al. 1963), the results in the present experiments suggest that palmitic acid may be elongated to stearic acid and further desaturated to oleic acid.

Although in Table 8 the results for milk fat composition are given only for the last 8 days of each experimental period, the effects of changing the dietary fat were noted as early as the 2nd day after the introduction of the new diet, and became fully established by the 6th day.

It is clear that further work is required on the effect of dietary fat on plasma triglyceride concentrations, with basal diets providing an even lower intake of fat than ours. Also, the level of dietary fat which limits milk fat synthesis needs to be more clearly defined. These two aspects are now being considered by comparing a basal diet low in fat with the same diet to which various amounts of a single fat have been added.

We thank Mr B. Tuckley, Mr D. Millard, Mr A. F. Hamnett and Miss S. Rigby for skilled technical assistance, Mr V. W. Johnson for care of the experimental animals and Dr S. J. Rowland for help with the preparation of the manuscript.

\section{REFERENCES}

Annison, E. F. (1960). Aust. F. agric. Res. II, 58.

Barry, J. M. (1964). Biol. Rev. 39, 194.

Barry, J. M., Bartley, W., Linzell, J. L. \& Robinson, D. S. (1963). Biochem. Y. 89, 6.

Bender, R. C. \& Maynard, L. A. (1932). F. Dairy Sci. 15, 242.

Bohman, V. R. \& Lesperance, A. L. (1962). F. Anim. Sci. 21, 658.

Bohman, V. R., Wade, M. A. \& Torell, C. (1959). F. Anim. Sci. 18, 567.

Bohman, V. R., Wade, M. A. \& Torell, C. (I962). F. Anim. Sci. 21, 24I.

British Standards Institution (1955). British Standard 696: Part I, p. 7. London: British Standards Institution. 
Brown, J. B. \& Sutton, T. S. (193 I). F. Dairy Sci. 14, 125.

Brown, W. H., Stull, J. W. \& Stott, G. H. (1962). F. Dairy Sci. 45, 191 .

deMan, J. M. (1964). F. Dairy Sci. 47, 546.

Farquhar, J. W., Insull, W. Jr, Rosen, P., Stoffel, W. \& Ahrens, E. H. Jr (1959). Nutr. Rev. 17, Suppl.

Garner, F. H. \& Sanders, H. G. (1938). F. agric. Sci., Camb. 28, 541.

Garton, G. A. (1960). Nutr. Abstr. Rev. 3o, I.

Garton, G. A. (1963). F. Lipid Res, 4, 237.

Garton, G. A. (1965). In Physiology of Digestion in the Ruminant, 1964, p. 390. [R. W. Dougherty, R. S. Allen, W. Burroughs, N. L. Jacobson and A. D. McGillard, editors.] Washington: Butterworths.

Glascock, R. F., Duncombe, W. G. \& Reinius, L. R. (1956). Biochem. 7, 62, 535.

Glascock, R. F., McWeeny, D. J. \& Smith, R. W. (1957). Proc. int. Conf. Radioisotopes scient. Res. I Paris, Vol. 3 , p. 146.

Glascock, R. F., Welch, V. A., Bishop, C., Davies, T., Wright, E. W. \& Noble, R. C. (1966). Biochem. F. 98,149 .

Hartmann, P. E., Harris, J. G. \& Lascelles, A. K. (I966). Aust. F. biol. Sci. r9, 635.

Hartmann, P. E. \& Lascelles, A. K. (1964). Aust. F. biol. Sci. 17, 935.

Hilditch, T. P. \& Sleightholme, J. J. (1930). Biochem. F. 24, 1098.

Holland, E. B., Garvey, M. E., Pierce, H. B., Messer, A. C., Archibald, J. G. \& Dunbar, C. O. (I923). 7. agric. Res. 24, 365 .

Huggett, A. St. G. \& Nixon, D. A. (1957). Biochem. F. 66, 12 P.

Lascelles, A. K., Hardwick, D. C., Linzell, J. L. \& Mepham, T. B. (1964). Biochem. 7. 92, 36.

Leat, W. M. F. \& Gillman, T. (1964). In Metabolism and Physiological Significance of Lipids, 1963, p. 257.

[R. M. C. Dawson and D. N. Rhodes editors.] London: John Wiley and Sons Ltd.

McCay, C. M. \& Maynard, L. A. (1935). F. biol. Chem. 1o9, 29.

McDowell, F. H., Reid, C. S. W. \& Patchell, M. R. (1957). N.Z. Fl Sci. Technol 38 A, 1054.

Maynard, L. A. \& McCay, C. M. (1929-30). F. Nutr. 2, 67.

Maynard, L. A. \& McCay, C. M. (1932). Bull. Cornell agric. Exp. Stn no. 543.

Maynard, L. A., McCay, C. M. \& Madsen, L. L. (1936). F. Dairy Sci. 19, 49.

Mohammed, K., Brown, W. H., Riley, P. W. \& Stull, J. W. (1964). F. Dairy Sci. 47, 208.

Moore, L. A., Hoffman, G. T. \& Berry, M. H. (1945). F. Dairy Sci. 28, 161.

Parry, R. M. Jr, Sampugna, J. \& Jensen, R. G. (1964). F. Dairy Sci. 47, 37.

Petersen, W. E. (1932). F. Dairy Sci. 15, 283.

Reid, R. L. (1960). Analyst, Lond. 85, 265.

Rook, J. A. F. (1961). Dairy Sci. Abstr. 23, 25 I.

Scarisbrick, R. (1952). Biochem. $\mathcal{F} .50$, xxxiv.

Shaw, J. C. \& Ensor, W. L. (1959). F. Dairy Sci. 42, 1238.

Storry, J. E. \& Millard, D. (1965). F. Sci. Fd Agric. I6, 4 I7.

Storry, J. E. \& Rook, J. A. F. (1964). Biochem. F. 91, 27 c.

Storry, J. E. \& Rook, J. A. F. (1965). Biochem. F. 96, 2 10.

Stull, J. W., Harland, F. G. \& Davis, R. N. (1957). F. Dairy Sci. 40, 1238.

Sutton, J. D. (1965). Rep. Prog. appl. Chem., 1964, 49, 239.

Tove, S. B. \& Mochrie, R. D. (1963). F. Dairy Sci. 46, 686.

Van Soest, P. J. (1 963). F. Dairy Sci. 46, 204.

Williams, H. H. \& Maynard, L. A. (1934). F. Dairy Sci. r7, 223. 